\title{
Study on the Relationship between Executive Compensation and Corporate Social Responsibility
}

\author{
Mengfei Sun ${ }^{1,2, a}$ and Yuanyuan Tian ${ }^{1, b^{*}}$ \\ ${ }^{1}$ Zaozhuang University, Zaozhuang 277160, China \\ ${ }^{1}$ Zhejiang University of Finance \& Economics, Hangzhou 310018, China \\ a594166053@qq.com, ${ }^{\mathrm{b}}$ moralist@126.com
}

\begin{abstract}
Keywords: Executive compensation; Corporate social responsibility taking; State-owned enterprises; Non-state-owned enterprises
\end{abstract}

\begin{abstract}
This paper is aimed to research the relationship between executive compensation and corporate social responsibility, and based on the public companies' financial information from 2011 to 2015. The conclusion is that the executive compensation is positive correlated to corporate social responsibility, as the improvement of executive compensation would improve the corporate social responsibility, and the corporate social responsibility in state-owned enterprises is better than in non-state-owned enterprises.
\end{abstract}

\section{Introduction}

Recent years, the public is increasingly paying attention to the condition that a corporate takes its social responsibility, and disclosure the information of corporate social responsibility taking is gradually becoming the New Normal [1]. In 2015, 707 companies disclosed the Social Responsibility, but there are only 471 companies disclosed Social Responsibility in 2010. This number increased 50.1\% over these years.

In current economic environment, due to the departure of proprietorship and the right of management, one corporation taking social responsibility mostly depends on the executives. So, higher executive compensation and proper incentives could motivate managers to take the corporate social responsibility [2]. Most studies are about the relationship between executive compensation and the financial performance [3], but it is possible that the executives could blend much personal benefits into the work and would overly pursue the better financial performance associated with their benefits[4], and therefore, could ignore the social responsibilities that the company could have taken[5].

This paper is going to investigate how the executive compensation affects the social responsibility taking. In addition, the paper would discuss the influence of different states of companies on social responsibility taking.

\section{Research Questions and Hypothesis}

Executive Compensation and Social Responsibility Taking. The managers are devoted to perform the corporate social responsibility to maintain a positive self-image and reach the expectation of the public about the corporate. In addition, many executives attach importance to the economic benefits gained by taking social responsibility, improve the financial performance through improved reputation obtained by fulfilling social responsibility, and further, increase their compensation [6]. The first hypothesis: The social responsibility taking is positive correlated to executive compensation.

Effect of Different State on the Relationship. State-owned enterprises (SOEs) and non-state-owned enterprises (NSOEs) are two groups of company form. In China, unlike the NSOEs, the SOEs operate not only for pursuit of financial benefits, but also shoulder the social responsibilities, such as motivating social stability [7]. However, the NSOEs mostly focus on the corporations' survival and development and aim to increase the corporation's value [8]. The NSOEs could set up a good appearance by taking social responsibility, and therefore gain the potential financial value, so the NSOEs 
could control the social responsibility more freely. Also, the pay level of NSOEs mainly depends on market, yet the base of SOEs' pay level could involve non-market oriented factors which could influence the social responsibility. The second hypothesis: Executive compensation has greater influence on social responsibility taking in the SOEs than in the NSOEs.

\section{Designs}

Data Selection and Variables. 100 corporations were selected, and these companies' related financial data from 2011 to 2015 are as sample data. To improve the accurate of the result, the companies that were special handled like HK, ST companies, that financial information was unclearly or wrongly disclosed, that obtained qualified audit opinion were taken out. Eventually, the paper is based on 500 samples.

Table 1 Variables

\begin{tabular}{|c|c|c|c|}
\hline & Independent variable & Symbol & Interpretation \\
\hline \multirow{4}{*}{$\begin{array}{c}\text { Corporation Social } \\
\text { Responsibility } \\
\text { (CSR) }\end{array}$} & Payable tax & Ptax & Payable tax \\
\cline { 2 - 4 } & Total profit & Tp & Total profit \\
\cline { 2 - 4 } & Employment & Emp & Employment \\
\cline { 2 - 4 } $\begin{array}{c}\text { Executive } \\
\text { Compensation }\end{array}$ & Interest expense & Le & Interest expense \\
\hline \multirow{4}{*}{\begin{tabular}{c} 
Executive compensation \\
\cline { 2 - 3 }
\end{tabular}} & Pay & Log of the three largest Executive compensation \\
\cline { 2 - 4 } & Supervisors & State & SOEs as 1, NSOEs as 0 \\
\cline { 2 - 4 } & Duality & Dul & Number of Supervisors \\
\cline { 2 - 4 } & Size & Size & Duality as 1, not duality as 0 \\
\cline { 2 - 4 } & Leverage & Lev & Log of total assets \\
\cline { 2 - 4 } & Industry & Indu & Total liability / total assets \\
\cline { 2 - 4 } & Year & Year & Industry the company's in \\
\cline { 2 - 4 } & Own & Own & Dhe proportion of largest shareholding \\
\hline
\end{tabular}

Model establishment. Basing on the theoretical analysis and hypothesis, the paper establishes the regression model to investigate whether increasing the executive compensation could stimulate the social responsibility taking:

$\mathrm{CSR}=\alpha_{1}+\beta_{1}$ PAY $+\beta_{2}$ STATE $+\beta_{3}$ Sups $+\beta_{4}$ Dul $+\beta_{5}$ Size $+\beta_{6}$ Lev $+\beta_{7}$ Ind $+\beta_{8}$ Year $+\beta_{9}$ Own $+\varepsilon_{1}$

Where $\alpha_{1}$ is constant, $\beta_{1}-\beta_{9}$ are regression coefficient, and $\varepsilon_{1}$ is residual. When CSR is calculated, the following two formulas are used. In these formulas, four variables: payable tax, total profit, interest expense and employment expense are used. Those four variables represent four major factors of social responsibility [9].

SOEs: CSR=0.241Emp+0.515Ptax+0.496Tp-0.183Le

NSOEs: $C S R=0.013 \mathrm{Emp}+0.751 \mathrm{Ptax}+0.573 \mathrm{Tp}-0.111 \mathrm{Le}$

\section{Regression Analysis}

Executive Compensation and Social Responsibility. Before the regression analysis, correlation analysis has showed that executive compensation is strongly correlated with social responsibility taking. The result from PSS24.0 is shown in Table $2 \sim 4$. It's apparent that the adjusted R square is $48.8 \%$, so the degree of fitting is not perfect. But, because the adjusted $\mathrm{R}$ square in most related studies is below $50 \%$, the $48.8 \%$ is acceptable. The sig. is 0.00 , which means the regression equation reaches $1 \%$ significance level and has statistical significance. According to the table above, the regression model has a correlation coefficient of 0.228 and a level of confidence of $99 \%$, which means the model passes the 
validation of regression equation and executive compensation is positively related to social responsibility taking. Therefore, the first hypothesis is justified.

Table 2 Regression Analysis

\begin{tabular}{|c|c|c|c|c|c|}
\hline Model & $\mathrm{R}$ & $\mathrm{R}$ square & Adjusted R square & $\mathrm{F}$ & sig. \\
\hline 1 & .705 & .497 & .488 & 53.118 & 0.00 \\
\hline
\end{tabular}

Table 3 Correlation Coefficient

\begin{tabular}{|c|c|c|c|}
\hline & Beta & $\mathrm{t}$ & Sig. \\
\hline Pay & $.228^{* * *}$ & 3.218 & .000 \\
\hline State & $.138^{* * *}$ & 9.038 & .000 \\
\hline Sups & $.089^{* *}$ & 1.179 & .031 \\
\hline Dul & .023 & 1.181 & .478 \\
\hline Size & $.702^{* * *}$ & 12.085 & .000 \\
\hline Lev & -.026 & -1.121 & .263 \\
\hline Industry & $-.142^{* * *}$ & -.3665 & .000 \\
\hline Year & -.022 & -.704 & .482 \\
\hline own & -.014 & -1.545 & .123 \\
\hline
\end{tabular}

Table 4 Grouped Correlation Coefficient

\begin{tabular}{|c|c|c|c|c|}
\hline \multirow{2}{*}{} & \multicolumn{2}{|c|}{ SOEs } & \multicolumn{2}{c|}{ NSOEs } \\
\cline { 2 - 5 } & Beta & Sig. & Beta & Sig. \\
\hline Pay & $.071 * * *$ & .000 & $.181 * * *$ & .001 \\
\hline Sups & $.049 *$ & .099 & $.091 * * *$ & .002 \\
\hline Dul & .026 & .510 & $-.090 *$ & .098 \\
\hline Size & $.703 * * *$ & .000 & $.417 * * *$ & .000 \\
\hline Lev & -.036 & .462 & .133 & .056 \\
\hline Industry & $-.111 * *$ & .014 & $-.232 * * *$ & .000 \\
\hline Year & -.031 & .427 & .016 & .764 \\
\hline own & -.021 & .124 & -.069 & .251 \\
\hline
\end{tabular}

note: ${ }^{*} \mathrm{p}<0.1,{ }^{* *} \mathrm{p}<0.05,{ }^{* * *} \mathrm{p}<0.01$

Effect of Different State on the Relationship. According to the result above, the adjusted R square of SOEs is $50.2 \%$, and the adjusted R square of NSOEs is $58.1 \%$. Both groups pass the validation of regression equation, reach the $1 \%$ significance level, and have positive correlation coefficient, which confirm the first hypothesis again. The correlation coefficient in the group SOEs is 0.071 that is lower than the 0.181 in group NSOEs, which indicates executive compensation of NSOEs is more related to social responsibility taking than that of SOEs. Therefore, the second hypothesis is justified.

\section{Summary}

From all the analysis above, two conclusions is soundly set up. One is that the social responsibility taking is positive correlated to executive compensation. With the increase in executive compensation, more social responsibility would be better performed. Once the executives obtain higher salaries, they would 
have the motivations to consider the long-term development for the companies, and taking social responsibility is a good strategy for the long-term.

The second is that executive compensation has greater influence on social responsibility taking in the SOEs than in the NSOEs. This could be caused by the NSOEs' compensation condition better fitting the free market[10]. The NSOEs perform social responsibility due to willingness, rather than only political tasks. However, some SOEs take social responsibilities because of political duty which might have negative effect on their companies. Hence, executive compensation has greater influence on social responsibility taking in the SOEs than in the NSOEs.

\section{Acknowledgements}

This work is supported by Shandong provincial natural science foundation (No. ZR201702200400); Science and technology program of Shandong higher education institutions (No. J17KA087); The program of independent innovation and achievement transformation plan for Zaozhuang (No. 2016GH19); Science and technology program of Zaozhuang (No. 2016GX31); The educational reform key projects of Zaozhuang University.

\section{References}

[1] R.M.Haniffa, T.E.Cooke: The Impact of Culture and Governance on Corporate Social Reporting, Journal of Accounting and Public Policy, Vol.24(2005), P391.

[2] O.Falck, S.Heblich: Corporate social responsibility: Doing well by doing good, Business Horizons, Vol.3(2007), P 247.

[3] J.Nollet,G.Filis and E.Mitrokostas: Corporate Social responsibility and financial performance: A non-linear and disaggregated approach, Economic Modelling, Vol.52(2016), P400.

[4] R.Lanis, G.Richardson: Corporate Social Responsibility and tax aggressiveness: an empirical analysis, Account. Public Policy, Vol.31(2012), P81.

[5] Cochran, L.Philip: Corporate social responsibility and financial performance, Academy of Management Journal, Vol.27(1984), P42.

[6] K.J.Sigler: CEO Compensation and Company Performance, Business and Economics Journal, Vol.31( 2011), P1.

[7] G.Robert, M.Kevin : Relative Performance Evaluation for Chief Executive Officers, Industrial and Labor Relations Review, Vol.43(1990)No.3, P30.

[8] S.L. Matthew: The Link between CEO Compensation and Firm Performance: Does Simultaneity Matter? Atlantic Economic Journal, Vol.50(2006) No.34, P101..

[9] E. Ortas: The impact of institutional and social context on corporate environmental, Social and governance performance of companies committed to voluntary corporate social responsibility initiatives, Journal of Cleaner Production, Vol.108(2015), P673.

[10] J.Martin: Executive compensation and corporate governance in China, Journal of Corporate Finance, (2011)No.3, P1158. 